STUDI

FRANCESI
Studi Francesi

Rivista quadrimestrale fondata da Franco Simone

152 (LI | II) | 2007

Varia

\title{
Images du temps, pensée de l'histoire, textes réunis et présentés par Christian Chelebourg
}

\section{Laurence Richer}

\section{(2) OpenEdition}

1 Journals

\section{Édition électronique}

URL : https://journals.openedition.org/studifrancesi/45952

DOI : 10.4000/studifrancesi.45952

ISSN : 2427-5856

Éditeur

Rosenberg \& Sellier

\section{Édition imprimée}

Date de publication : 1 octobre 2007

Pagination : 453-454

ISSN : 0039-2944

\section{Référence électronique}

Laurence Richer, «Images du temps, pensée de l'histoire, textes réunis et présentés par Christian

Chelebourg », Studi Francesi [En ligne], 152 (LI | II) | 2007, mis en ligne le 30 novembre 2015, consulté le 24 novembre 2021. URL : http://journals.openedition.org/studifrancesi/45952 ; DOI : https://doi.org/ $10.4000 /$ studifrancesi.45952

Ce document a été généré automatiquement le 24 novembre 2021.

\section{(c) $($ ) $\odot$}

Studi Francesi è distribuita con Licenza Creative Commons Attribuzione - Non commerciale - Non opere derivate 4.0 Internazionale. 
Images du temps, pensée de l'histoire, textes réunis et présentés par Christian Chelebourg

Laurence Richer 


\section{RÉFÉRENCE}

Images du temps, pensée de l'histoire, textes réunis et présentés par Christian CHELEBOURG, «Écritures XIX», 2, Minard, «Lettres modernes», 2005, pp. 212.

1 Ce deuxième numéro d'une série consacrée plus spécialement au xix ${ }^{e}$ siècle par les publications Minard offre un intéressant ensemble pour la première moitié du siècle. Eu égard au sujet, on peut lui savoir gré de s'ouvrir par un article (Laure KATSAROs, pp. 35- 47) consacré à l'Histoire de la Révolution de Michelet, puis par un article sur Tocqueville (Hervé GUINERET, pp. 49-67), qui évitent l'un et l'autre les chemins critiques les plus frayés autour de ces œuvres. C'est sur la décadence des civilisations que se construisent les pages consacrées à Daphné de Vigny (Isabelle CASTA, pp. 89-104). La lumineuse synthèse proposée par Michel BRIX (pp. 115-132) nous conduit de Rousseau à Proust pour mieux mettre en valeur la saisie romantique du rapport entre le moi, la mémoire et le monde. «Parce qu'elle dérive du travail du souvenir, l'œuvre naît toujours au moment où l'oubli menace» (p. 129): l'affirmation, au-delà de Nerval, est fondamentale pour une poétique. Remarquons la cohérence entre cet article et la réflexion de Philippe ANTOINE (pp. 161-174), pour qui le Moyen Âge de Chateaubriand est une «histoire fictive» (p. 161), fondant un système de représentations, pictural et littéraire. Christian CHelebourg (pp. 175-196) cherche dans l'écriture épique de la Légende des siècles la conciliation entre temps cyclique et temps linéaire, ce qui a préoccupé Michelet avant Hugo. Autant dire que ce recueil nous mène bien à l'essentiel du domaine abordé. 